\title{
A FORMAÇÃO CRISTÃ E O DIÁLOGO DOS PRIMEIROS PADRES COM O PAGANISMO DE SÊNECA
}

José Joaquim Pereira Melo*

\section{RESUMO}

Neste texto, apresentam-se algumas reflexões sobre o diálogo promovido pelo cristianismo dos primeiros séculos com o pensamento clássico romano, especialmente com Lúcio Aneu Sêneca (4 - 65). Procurando pontos de convergência que sustentassem e/ou legitimassem sua doutrina, os primeiros cristãos avaliaram aspectos morais do pensamento senequiano que pudessem ser utilizados na causa cristã. Autores cristãos, como Tertuliano (160 - 220), Lactâncio (250 - 325), Santo Ambrósio (340 - 397), São Jerônimo (347 - 420), Clemente de Alexandria (145 - 216) e Santo Agostinho (354 - 430), representando fases distintas do pensamento cristão, estabeleceram esse processo interativo, não apenas pelo objetivo de respaldar suas reflexões doutrinais, mas também para contribuir para a elaboração de um modelo de homem ideal para o cristianismo.

Palavras-chave: cristianismo, Sêneca, pensadores cristãos, formação.

\footnotetext{
* Universidade Estadual de Maringá (UEM), Maringá/PR, Brasil.
} 


\title{
LA FORMACIÓN CRISTIANA Y EL DIÁLOGO DE LOS PRIMEROS CURAS CON EL PAGANISMO DE SÉNECA
}

\section{RESUMEN}

En este texto, se presentan algunas reflexiones sobre el diálogo promovido por el cristianismo de los primeros siglos con el pensamiento clásico romano, especialmente con Lucio Anneo Séneca (4 - 65). En la búsqueda de puntos de convergencia que sostuvieran y o legitimaran su doctrina, los primeros cristianos evaluaron aspectos morales del pensamiento senequiano que pudieran ser utilizados en la causa cristiana. Autores cristianos como Tertuliano (160 - 220), Lactancio (250 - 325), San Ambrosio (340 - 397), San Jerónimo (347 - 420), Clemente de Alexandria (145 - 216) y San Agustín (354 - 430) que representan fases distintas del pensamiento cristiano, establecieron ese proceso interactivo, no solo con el objetivo de respaldar sus reflexiones doctrinarias, sino también para contribuir para la elaboración de un modelo de hombre ideal para el cristianismo.

Palabras-claves: cristianismo, Séneca, pensadores cristianos, formación.

\section{CHRISTIAN FORMATION AND THE DIALOGUE OF THE CHURCH FATHERS WITH SENECA'S PAGANISM}

\begin{abstract}
Current research discusses the dialogue between early Christians and Roman classic thought, especially Seneca ( $4-65$ EC), to discover convergent points that would support their ideas. A narrative was fabricated according to which he would be close to conversion. This would provide a base for the evaluation of the moral aspects of his philosophy and for its use in favor of the Christians. Christian authors, such as Tertullian, Lactantius, Jerome and Augustine will be underscored since these philosophers, representing distinct phases of Christian thought, perceived the track to an interactive process. Christian philosophers' esteem for Seneca made them redefine their thoughts on the doctrine they elaborated. The great representatives of Christian thought examined Seneca's philosophy on moral man's formation and endeavored to elaborate a Christian model of the ideal man.
\end{abstract}

Keywords: christianity, Seneca, christian thinkers, formation.

\section{FORMATION CHRÉTIENNE ET DIALOGUE DES PÈRES DE L'ÉGLISE AVEC LE PAGANISME DE SÉNÈQUE}

\section{RÉSUMÉ}

Les recherches actuelles traitent du dialogue entre les premiers chrétiens et la pensée classique romaine, en particulier avec Sénèque pour découvrir des points convergents qui soutiendraient leurs idées. Un récit a été fabriqué selon lequel il serait proche de la conversion. Cela fournirait une base pour évaluer des aspects moraux de sa philosophie et son utilisation en faveur des chrétiens. Les auteurs chrétiens Tertullien, Lactantius, Jérôme et Augustin seront soulignés 
puisque ces philosophes, représentant des phases distinctes de la pensée chrétienne, ont perçu la voie vers un processus interactif. L'estime des philosophes chrétiens pour Sénèque les a fait redéfinir leurs pensées sur la doctrine qu'ils élaborent. Les grands représentants de la pensée chrétienne ont examiné la philosophie de Sénèque sur la formation de l'homme moral et s'efforçent d'élaborer un modèle chrétien de l'homme idéal.

Mots-clés: christianisme, Sénèque, penseurs chrétiens, formation. 


\section{INTRODUÇÃO}

Neste texto, o objetivo é apresentar algumas reflexões históricoeducacionais a respeito do diálogo promovido pelo cristianismo dos primeiros séculos com o pensamento clássico, em seu recorte romano, especialmente com Lúcio Aneu Sêneca (4-65).

Antes de qualquer outra consideração, destaca-se a legitimidade, inicial ou potencial, do cristianismo ao apreciar a realidade de uma perspectiva humana, inserindo nela o que defendia como perfeição ética. Cabe também considerar que esse diálogo é interessante porque induz a pensar em questões teóricas importantes.

Da perspectiva teórica adotada neste texto, cada tempo histórico desenvolve, em sua dinâmica, novas formas de pensar o mundo, a sociedade e o homem, às quais correspondem novas práticas para o bem-viver. Esse processo desencadeia a inquietação de atores sociais específicos, que buscam outras formas de atender às necessidades que surgem, tendo em vista ordenar e conduzir a sociedade em que vivem.

Com esse entendimento de história, procurou-se desvendar os meandros das mensagens de alguns personagens que atuaram nos primeiros séculos do cristianismo, os movimentos e o diálogo que estabeleceram com a cultura clássica para fundamentar teoricamente o corpo doutrinal e formativo da Igreja no momento inicial de sua organização, quando se tratava de formar adeptos. A proposta implica, portanto, o procedimento metodológico de situar a ação desses personagens no movimento das relações sociais e materiais que então se constituíam.

A busca da herança clássica pelos Padres da Igreja, particularmente pelos que foram selecionados para a discussão, põe à luz a elaboração de um código de comportamento, não apenas moral e intelectual, mas também social a ser adotado pelo homem que se pretendia formar para o cristianismo. Isso marcou profundamente todo o magistério da Igreja. Tal inquietação e tal 
preocupação levaram esses primeiros pensadores cristãos a abrir e traçar caminhos para que seus sucessores disseminassem em seus magistérios o ideal formativo cristão.

A defesa da continuidade cultural e social faz parte da história humana, o que não significa uma negação do processo de transformação que a humanidade experimenta e, por sua vez, transforma, mas sim que a história não é linear. Figura, na busca pela preservação da existência, o compromisso do homem com a reiteração da cultura transmitida ao longo dos tempos (HOBSBAWM, 2004). É a partir dela que se institui um novo tempo, uma nova ordem social.

\begin{abstract}
Em suma, [...] é possível concluir que o novo só se estabelece na luta contra as velhas formas de comportamento, na utilização de materiais, suportes e subsídios do passado para justificar ou sedimentar os comportamentos emergentes. Por outro lado, isso permite também identificar as marcas que o passado deixa nos homens de outras épocas e em que circunstâncias isso acontece (PEREIRA MELO, 2010, p. 27-28).
\end{abstract}

Dessa perspectiva, as heranças do passado são as bases para a manutenção e a sobrevivência das gerações vindouras, ou seja, para a perpetuação de todo um legado social cultural produzido e acumulado por um povo (PEREIRA COELHO; PEREIRA MELO, 2017, p. 213).

O diálogo dos primeiros cristãos com o paganismo é o objeto de análise neste artigo. Na linha teórico-metodológica proposta, cabe relacioná-lo com a transformação histórica na qual duas ordens sociais se enfrentaram. Os cristãos se opunham à ordem hegemônica greco-romana, mas, contraditoriamente, pautaram-se em muitos aspectos de seu pensamento. O resultado desse movimento de aproximação do que se negava como "profano", do que atentava contra as "verdades cristãs", foi a seleção e a apropriação do que de melhor o saber clássico oferecia para atender ao interesse teórico-doutrinal e formativo da Igreja nos primeiros séculos do cristianismo. 
Vale lembrar que, dentre os pensadores clássicos, poucos foram tão bem acolhidos entre os primeiros autores cristãos quanto Lúcio Aneu Sêneca (4 65). Mesmo sabendo que esse filósofo não havia passado pelo batismo, eles o aproximaram estreitamente do cristianismo, tratando-o como uma espécie de vizinho espiritual do pensar inaugurado por Cristo.

Apontar a contradição inerente a esse acolhimento é central neste artigo, o que explica algumas dificuldades na seleção das fontes secundárias atuais. Mesmo que a relação entre o cristianismo primitivo e a cultura clássica tenha sido amplamente analisada em várias áreas do conhecimento, especialmente fora do Brasil, esse interesse perdeu espaço a partir da década de 1990 em favor de objetos de pesquisa contemporâneos. No Brasil, o interesse pela temática tem sido menor ainda.

É consenso na literatura que Sêneca provocou um profundo interesse entre alguns Padres da Igreja, mas a apropriação de seu pensamento na elaboração do conteúdo doutrinário para a formação cristã é pouco abordada. Portanto, o tratamento bibliográfico limitado também se aplica a essa questão, o que restringe a reflexão com base em fontes bibliográficas especificas e atualizadas. Embora com fontes mais ou menos restritas, é possível abordar o tema com base em fontes do passado, já consagradas como clássicas, e encontrar na confluência contraditória do cristianismo com Sêneca elementos para refletir sobre a formação do homem cristão como uma questão histórica que pode abrir espaço para novas reflexões.

Na análise, privilegiam-se Tertuliano (160 - 220), Lactâncio (250 325), Santo Ambrósio (340 - 397), São Jerônimo (347 - 420), Clemente de Alexandria (145 - 216) e Santo Agostinho (354 - 430) porque se entende que cada um desses pensadores, representando fases distintas do pensamento cristão, soube expressar o direcionamento dado a esse processo interativo. Dentre os pensadores clássicos, privilegia-se o pensamento de Sêneca porque sua reflexão a respeito da formação de um homem ideal também se fazia de uma perspectiva genuinamente humana. 


\section{SÊNECA NA CONFLUÊNCIA ENTRE PAGANISMO E CRISTIANISMO}

Não se pode negar o mérito senequiano na questão da autonomia ética diante de todo condicionamento da virtude, inferior à mesma virtude. É preciso considerar que ainda não se constituíra o formalismo kantiano da virtude pelo dever ou da virtude fundada no dever pelo dever: Sêneca se referia ao valor interior que próprio homem atribuía a si. Ou seja, falava de um humanismo "imediato", diferente do humanismo "mediato" teorizado por Kant (1724 1804). Quer dizer, ele se referia a uma virtude cujo fim seria ela mesma, correspondente ao fim último, absoluto e radical do conteúdo e do valor da “salvação" preconizada pela práxis cristã.

A rigor, pode-se dizer que o valor ético defendido por Sêneca, a exemplo de qualquer outro estoico, socrático e epicurista, correspondia a um ideal antropológico-natural lastreado no esforço pessoal (GÓMEZ MARTÍNEZ, 1966, p. 138-139). Tais sistemas filosóficos, ou seja, estoico, socrático e epicurista, com o passar do tempo, foram se aproximando ideologicamente e o século I d. C. foi o maior marco desse contato.

Foi nesse século que Sêneca desenvolveu seu pensamento, fundamentando-se em sentenças dos fundadores dessas escolas e de seus continuadores, como Epicuro, a quem dedica elogios e declara admiração: "há esse dito notável de Epicuro" (SÉNECA, 1991, p. 17). Sêneca nem sempre teve dúvidas ao rever o que diziam seus antecessores, como fez com o próprio Epicuro: "para Sêneca a medida da riqueza é ter não apenas o necessário, seja muito ou pouco, mas o suficiente, e não querer mais, enquanto para Epicuro era ter apenas o que era necessário e ser alegre" (RODRÍGUEZ FERNÁNDEZ, 1996, p. 330).

É um bem desejável conservar a alegria em plena pobreza. E com razão, pois se há alegria não pode haver pobreza: não é pobre quem tem pouco, mas sim quem deseja mais. Que importa o que temos no 
cofre, ou nos celeiros, quantas cabeças de gado ou quanto capital a juros, se fizermos as contas não ao que possuímos, mas ao que queremos possuir? Queres saber qual a justa medida das riquezas? Primeiro: aquilo que é necessário; segundo: aquilo que é suficiente! (SÉNECA, 1991, p. 4)

Sêneca também se contrapôs ao "Mestre do Jardim" ao afirmar que morte pressupõe o "nascimento para a eternidade” (SÉNECA, 1991, p. 566).

Muitos entendem que Sêneca pensava como um cristão em uma supervivência pessoal. Para os defensores dessa tese, esse pensar é indicativo da relação íntima que ele tinha com o cristianismo, que só não foi a público pelas possíveis consequências adversas de tal declaração (RODRÍGUEZ FERNÁNDEZ, 1996, p. 330).

Uma leitura ancorada em Cartas a Lucílio pode levar ao entendimento de que são muitas as semelhanças entre o pensar senequiano e o pensamento cristão. O filósofo se referia a virtudes naturais, promovidas pelas descobertas, pela própria inteligência, e não a virtudes de caráter sobrenatural que requeriam uma revelação. Ele tratava de ética, não de moral em sua dimensão estrita. Ademais, eram ideias de caráter teórico, não prático e, no que se refere à divindade, de nível natural, não implicando nenhuma ordem sobrenatural, conforme acontecia com as virtudes, a caridade ou amor a Deus (virtude não ética, senão moral), ou com a visão de que Cristo não era um homem simples (verdade especulativa sobrenatural, não prática). Quanto à vida, à práxis, Sêneca mesmo deixou claro que não transcendia o plano natural e se referia à existência de versos eloquentes que borbulhavam na cabeça dos mimos, como os dos poetas trágicos, e que seriam próprios de filósofos (RODRÍGUEZ FERNÁNDEZ, 1996, p. 331), conforme correspondência enviada para o amigo e discípulo Lucílio:

Quantos poetas há que já disseram o que os filósofos ou já disseram também ou hão-de dizer um dia! [...] até nos mimos, que quantidade se não encontra de versos excelentes! Quantos versos não escreveu 
Publílio dignos de personagens de coturno, e não de gente descalça! Vou citar-te um verso dele que trata matéria filosófica (SÉNECA, 1991, p. 20).

Em Sêneca, tais ideias e/ou verdades eram de sentimento comum, ditadas pela natureza. Em sua argumentação, ele deixava esse pensamento explícito: "E para que vejas como este pensamento foi ditado pela natureza à sabedoria popular” (SÉNECA, 1991, p. 27-28).

Por seu turno, o ideal cristão, com suas bases teológicas-sobrenaturais, remetia a Deus, àquilo que seria sua melhor parte (GÓMEZ MARTíNEZ, 1966, p. 138-139), ou seja, à graça salvífica, obra e dádiva de sua misericórdia infinita.

Apesar das grandes diferenças que particularizaram esses pensares, na contramão da maioria dos críticos de Sêneca que se opunham ao seu pensamento e à sua prática política, os cristãos se voltaram para suas ideias, suas sentenças e sua doutrina. Assim, geraram em alguns a noção comum e aceita de um Sêneca pagão, mas quase precursor da doutrina cristã e, em outros, a noção de um Sêneca às vésperas da conversão ao cristianismo.

Acrescenta-se a essa construção narrativa mais três questões significativas: o irmão mais velho de Sêneca, Lúcio Júnio Galio (4 a.C. - 65 d. C.), teria conhecido Paulo de Tarso (5 - 67); Sêneca tinha uma visão sobre a divindade que permitia pensar que ele acreditava em um deus único, criador e senhor do mundo e dos destinos humanos; a moral que ele defendia era muito semelhante à moral postulada pelos cristãos (MANJARRÉS, 2001).

Para além dessas três questões, foi sua discussão moralista que mais chamou a atenção dos cristãos e de seus pensadores. Em razão desse despertar, os primeiros cristãos incluíram aspectos do pensamento senequiano no âmbito cristão.

É preciso considerar que os primeiros cristãos não se preocupavam com a teorização do ser, com discussões metafísicas ou filosóficas: sua grande preocupação era a mensagem deixada por Cristo, a qual tinha um viés 
inteiramente prático. As reflexões sobre o mundo somente teriam sentido se estivessem voltadas para o destino sobrenatural do homem.

A especulação natural, como a desenvolvida pelos pensadores escolásticos da medievalidade, não teve espaço na Patrística, movimento que privilegiou reflexões sobre salvação, problemas teológicos e morais, controvérsias com os considerados pagãos e hereges. A filosofia inoculada no período, até mesmo em seus expoentes, como Santo Agostinho (354 - 430), não foi além desse quadrante. Os pensadores clássicos não despertavam interesse porque refletiam sobre o ser das coisas, mas sim porque argumentavam sobre o homem, sobre Deus e sobre a alma, discutindo temáticas destinadas a orientar o homem a proceder melhor para ter uma vida virtuosa. Assim, os ensinamentos bíblicos cumpriam seu papel, preenchendo todas as lacunas e contentando seus adeptos. Isso significa que a cosmovisão bíblico-cristã pouco ou nada tinha a acrescentar àqueles preocupados com a ciência produzida pelos homens. Seus pensares foram ocasionalmente convocados para fortalecer as verdades cristãs. Ao que tudo indica, em um mundo que se particularizou pelo dogmatismo e pela moral, a preocupação moral defendida por Sêneca oferecia complementos significativos e valiosos para a prática cristã, entendida como a verdade plena, o que se tornou motivo e/ou justificava bastante forte e coerente para sua aceitação entre os cristãos.

Dentre as especulações naturais de Aristóteles (384 - 322), de outros pensadores clássicos e de Sêneca, os Padres da Igreja contemplaram este último como um romano decepcionado e inconformado com o mundo sensível e que, por isso, voltava sua preocupação e exortação para a vida interior. Sêneca se dedicava a libertar o espírito dos apelos da carne e das seduções do mundo e isso remetia às instruções paulinas de embate entre o homem somatikós e homem pneumatikós, as quais se assemelhavam ao enfrentamento dialético senequiano, no vir bonus, vir fortis, contra a fortuna, as paixões, as honrarias, entre tantos outros apelos do mundo. Em Sêneca, assim como no estoicismo, o que se opunha à virtude da alma era o corpo, a matéria (GÓMEZ MARTINÉZ, 
1966, p. 140), os atrativos e apelos do mundo exterior que encantavam e atraíam o homem para seus domínios.

A importância dessa relação do cristianismo com Sêneca pode ser dimensionada pelo suposto epistolário entre Sêneca e Paulo de Tarso. Essa correspondência apócrifa foi comentada pela primeira vez em 392 por São Jerônimo (347 - 420) (ULLMANN, 1996), em De viris illustribus.

[...], essas cartas tão lidas hoje por muitos de Paulo a Sêneca e de Sêneca a Paulo. Preceptor de Nero, nessa época sumamente poderoso, expressa em suas cartas, que desejava ocupar entre os seus o lugar que Paulo ocupava entre os cristãos. Parece vítima da crueldade de Nero dois anos antes do martírio de Pedro e Paulo (SAN JERÓNIMO, 1999, p. 17-18).

Em sua alegação, São Jerônimo apresentou uma linha argumentativa de que teria havido uma repercussão das ideias senequianas entre os primeiros pensadores cristãos. Nesses mesmos comentários, ele pôs em tela a vida do pensador como "admirável continência" (SAN JERÓNIMO, 1999, p. 17). Em que pese a palavra ter sido bem medida, esse tratamento louvatório ficou circunscrito ao aspecto ascético, já que o autor tinha conhecimento de que a vida da personagem em apreço não era tão admirada por muitos (ELORDUY, 1965).

No cenário de um cristianismo que buscava sustentação filosófica para sua doutrina, o que importa nessa alusão de San Jerônimo não é sua avaliação pessoal da informação, mas a opinião que os cristãos tinham dessa relação entre Paulo e Sêneca. São Jerônimo, muito provavelmente motivado pelas ideias correntes entre os cristãos, foi induzido a contar o filósofo entre os santos (SAN JERÓNIMO. 1999, p. 17), conforme a justificativa que se encontra em De viris illustribus: "Lucio Anneo Sêneca, de Córdoba, discípulo do estoico Socion, sogro do poeta Lucano, passou sua vida em uma continência admirável. Não o incluiria no catálogo dos santos, se não me tivessem determinado isso essas 
cartas" (SAN JERÓNIMO, 1999, p. 17-18). Outro fato que merece destaque é a realização de um plebiscito da Igreja primitiva para discutir as relações íntimas de Sêneca com o cristianismo e, nesse fórum, as ditas correspondências entre Paulo e Sêneca (ELORDUY, 1965, p. 182). Muito já se escreveu sobre o valor histórico desse documento literário, a respeito do qual se dividem partidários e rejeitadores de sua autenticidade: coube à historiografia elucidar sua condição apócrifa. Isso se explica pela falta de evidências históricas desse evento celebrado pelos cristãos dos primeiros tempos, assim como pelo fato de o filósofo e o apóstolo terem se conhecido e também por Sêneca ter conhecido a doutrina cristã, uma vez que esta, em seu alvorecer, era ignorada e desprezada pelos setores dominantes da sociedade romana da qual ele fazia parte.

Santo Agostinho, um dos maiores nomes do cristianismo, foi um dos primeiros pensadores cristãos a criticar Sêneca com certa severidade (OROZ RETA, 1996). No entanto, ele também se referiu às supostas cartas trocadas entre Paulo e Sêneca em sua Epistola 153, V: “[...] Sêneca (que viveu no tempo dos apóstolos, e cujo nome figura em algumas epístolas dirigidas ao apóstolo Pablo)" (SAN AGUSTIN, 1953, p. 349).

Nessa epístola ele relatou uma reclamação de Macedônio, vicarius da África (413 - 414), contra eclesiásticos que apelavam em favor de criminosos e ficavam ofendidos quando suas recomendações não eram atendidas. A resposta agostiniana foi respaldada na autoridade senequiana (ELORDUY, 1965): ele evocou seu pensar a respeito do amor ao próximo, mesmo que mal, pois a caridade universal era para todos os homens: "Com razão disse Séneca [...]: “Odeio a todo o que odeia aos maus". E, não obstante, temos que amar os maus para que não sejam maus, como se ama os enfermos, não para que durem, mas para que se curem" (SAN AGUSTIN, 1953, p. 349).

Assim, o fato de Sêneca pertencer ao pensamento pagão não afetou a simpatia que pensadores cristãos nutriam por ele, a ponto de nele encontrarem inspiração para redefinir suas ideias e reordenar sua doutrina (ULLMANN, 1996). Isso deveu-se ao fato de que, para o cristão, vivenciar sua religião e 
entregar-se a ela transcendia a ordem natural, o que era motivo suficiente para Sêneca aparecer nas pautas de Padres da Igreja como um modelo que se distinguia pela superação do plano imediato, natural, no qual transitavam os homens habitualmente. Esse seria um diferencial entre Sêneca e os demais filósofos: na perspectiva dos cristãos, ele era um espírito com características superiores que buscava dimensões mais puras, mais desprendidas, menos contaminadas pelo material, pelo corpóreo e pelos sentidos. Em face disso, pouco faltava para que se hipotecasse a Sêneca, além dos dotes de transcendência espiritual, psicológica e prática, outra característica, a da transcendência ontológica. A linguagem de caráter piedoso que dedicava à divindade era suficientemente legítima para ser evocada como exemplo de diálogo de fé cristã com o pai, o Senhor de tudo e de todos, o Deus Pai Criador que, para o cristão, era princípio, fim e razão de todas as coisas (GÓMEZ MARTÍNEZ, 1966).

Os pensadores cristãos consideravam que, em Sêneca, a filosofia era um exercício que tinha como finalidade a salvação autêntica, não comprometida e/ou preocupada com reflexões vazias e pretensiosas a respeito dos mistérios da natureza. Por esse motivo, os cristãos puderam sentir certa linha, mesmo que tênue, de aproximação e afinidade espiritual com o seu pensar. Mesmo que destacassem que a distância diametral que os separava estava na essência dos dois pensamentos, o clima que pairava sobre eles favorecia semelhanças e aproximações significativas que não podiam passar despercebidas e desconsideradas, em razão da forma e do conteúdo que traziam consigo.

Ao que tudo indica, os Padres da Igreja, conforme designativo cristão, não consideravam Sêneca como um sábio "deste século" ou um sábio nos moldes clássicos, mas um "convertido", um devotado, um "missionário" da vida do espírito, um "salvo", um "regenerado", um "liberto", também segundo os dizeres cristãos, daquela geração má, infiel e decaída que necessitava ser regenerada (GÓMEZ MARTÍNEZ, 1966).

O que fica candente é que o que mais tocava esses homens da Igreja era 
que Sêneca explicava como se dava a realização desse processo de salvação, tão caro aos cristãos. Segundo o pensador, não era Deus, mas o próprio homem que esperava, ansiava e exigia de si mesmo a salvação. Assim, a vontade da salvação expressa passava pela vontade do próprio homem, cabia-lhe trilhar o caminho desse bem maior ensinado por Cristo e exortado por seus líderes. Isso explica, em muitos dos casos, por que eles reproduziram seus escritos e suas ideias sem ao menos citar Sêneca (ULMANN, 1996), que tanto admiravam e buscavam como referência para suas reflexões e exortações.

\section{ACEITAÇÃO E APROPRIAÇÃO DO PENSAMENTO PAGÃO ENTRE OS PRIMEIROS CRISTÃOS}

Neste texto, dividiu-se em duas fases o processo de aceitação de Sêneca por alguns pensadores da Igreja primitiva, em razão dos artifícios utilizados pelos mesmos para a incorporação do pensamento greco-romano ao cristianismo, por extensão, da paidéia clássica à paidéia cristã. Nesse exercício intelectual não tiveram maiores dificuldades para revestir seus escritos com um verniz literário, visto sua condição de homens formados, cultivados e qualificados pelo pensamento clássico, assim como pelo meio cultural em que transitavam.

Não se pode esquecer que nem todos os membros cultos da Igreja que buscavam consolidação e efetivação do pensar cristão adotaram a mesma atitude em relação à cultura clássica. Cada qual à sua maneira e conforme seu interesse, assumiu tendências diferenciadas (REDONDO; LASPALAS, 2002), mais ou menos avançadas, segundo os seus ambientes sociais e culturais, mais abertos ou fechados ao pensar que entendiam como pagão. Em razão disso, no exercício aqui pretendido, optou-se pelo recorte mais ou menos cronológico já mencionado.

Da primeira fase de aceitação do pensamento de Sêneca, selecionamos 
Clemente de Alexandria, Tertuliano e Lactâncio; da segunda, Santo Ambrósio, São Jerônimo e Santo Agostinho. Reitera-se aqui que esses pensadores ajudaram a dar sustentação filosófica aos fundamentos cristãos, cujo referencial, fundado na afetividade propagada por Jesus, buscava respaldo na racionalidade própria do pensar considerado pagão.

Em seu pensar e magistério, Clemente de Alexandria teve lugar privilegiado no grande movimento de interpretação, de assimilação e de síntese da cultura clássica na elaboração de diretrizes e respostas a questões significativas e básicas da religião, da filosofia, da moral e das letras, manifestando apreço, admiração e gratidão pelo pensar grego.

Confirmando o papel propedêutico que o saber clássico podia desempenhar, ele referiu-se também à possibilidade de este servir diretamente aos cristãos, para desenvolver e esclarecer as verdades da fé. Isso fica claro em suas reflexões sobre a possibilidade de alguém se tornar cristão sem ter o domínio das letras, mas, sem a ciência, não poder compreender todo o conteúdo proposto pela fé (GALINO, 1988).

Tal reflexão apontou seu talento "intelectual" e filosófico, sua atitude mais "aberta" e favorável à incorporação do que entendia "verdadeiro" e "valioso" do saber clássico (REDONDO; LASPALAS, 2002).

Em O Pedagogo, Clemente de Alexandria aspira à cultura clássica, à paidéia helênica. Cristo é apresentado em sua condição de mestre divino, cuja transcendência é maior do que qualquer outro modelo na história humana (JAEGER, 1998).

Para além, desenvolve nesse livro exortações sobre regras de vida referentes ao comportamento pessoal, à comunhão que deveria haver entre marido e esposa e à educação dos filhos, mostrando a influência que recebeu de Sêneca e de outros estoicos (ULLMANN, 1996).

Em seu magistério, no que diz respeito à situação religiosa e cultural, ele procedeu à crítica de algumas das manifestações pagãs, ao mesmo tempo em 
que acolheu outras posições. Sua crítica passava pelo politeísmo, pelos cultos mistéricos e pelos sacrifícios aos deuses "pagãos". Acatou discussões consideradas por ele como verdades às quais os filósofos chegaram, no caso em apreço, o estoicismo, que se faz presente em suas reflexões, embora sempre defenda participação do Logos divino.

Ancorado particularmente nas disposições morais afetas ao exercício da inteligência, quais sejam, o orgulho intelectual, o espírito sofístico, o racionalismo desmedido que solicita conclusões em terreno em que não é possível oferecer outra certeza que não a moral, o individualismo intelectual dos filósofos (GALINO, 1988, p. 381-382), marcou posição firme, o que o particularizou nesse processo de encontro entre esses dois pensares.

Tertuliano assumiu a postura radical de afirmar que muito pouco se poderia aprender com os pensadores clássicos.

Segundo defendia, as coisas referentes ao mundo deveriam ser examinadas à luz dos documentos que lhes são próprios. Foi além ao concluir: se não é facultado aos mestres cristãos ensinar o pensamento clássico, também não lhes é permitido aprendê-lo, ter acesso à forma "pagã" de pensar porque esta não se coaduna com a mensagem cristã. Nesse raciocínio, Tertuliano recolheu argumentos dos Padres Apologistas para desqualificar o pensamento clássico, cuja avaliação atingiu uma rigorosidade extremada (REDONDO; LASPALAS, 2002).

Esse mesmo ataque não adotou em relação a Sêneca. Recorreu aos pensares senequianos, contidos em Dos benefícios, por exemplo, para respaldar algumas de suas reflexões, como fica explícito em sua obra Acerca del alma. Nesse trânsito pelo pensamento de Sêneca, conforme o Livro XX, 1, dessa mesma obra, na qual Sêneca é chamado de "nosso", observa-se uma semelhança com as exortações que o filósofo deixou em Dos benefícios.

Aqui, pois, obtemos também aqui como conclusão que todas as qualidades da alma são inerentes a sua substância como conatural, e 
com ela crescem e se desenvolvem desde o instante em que ela se origina. Como também disse Séneca, com frequência $<<$ nosso $>>$ : subjacente em nós as sementes de todas as artes e idades, e o mestre Deus desde o oculto produzem os engenhos, das sementes subjacentes também ocultas durante a infância, que são igualmente a inteligência. Destas, pois, se produzem os engenhos (TERTULIANO, 2001, p. 88).

Umas das reflexões senequianas que mais apreço despertou em Tertuliano foi a distinção entre corpo e alma. Ao discutir essa questão, ele levou ao extremo seu pensamento ascético, contrapôs-se à materialidade humana $\mathrm{e}$ privilegiou o primado incondicional do espírito sobre a matéria e, assim, ultimou sua participação na Igreja e abraçou o Monatismo (GARCÍA GARRIDO, 1972).

Decorrido um século, a presença de Sêneca permaneceu viva no meio cristão.

Destaque nesse sentido merece Firmino Lactâncio, o orador e apologista que recebeu a alcunha de "Cícero cristão", por sua eloquência em favor da causa cristã. Em sua reflexão Sobre a morte dos perseguidores manifestou grande interesse pelo pensar de Sêneca. Isso fica evidente em seus escritos sobre o governo de Deus no mundo, os quais tiveram indiscutível influência das discussões senequianas contidas em sua Da providência (PEREIRA MELO, 2015).

Em Instituições divinas, Lactâncio, fez referências elogiosas a Sêneca, embora fossem recorrentes suas críticas ao pensamento clássico, que, para ele, não tinha consistência nem relevância. Ao mesmo tempo, brindou-o com adjetivos, advérbios e locuções que deixam transparente sua admiração pelo filósofo, como na citação a seguir.

Também Anneo Sêneca, que foi o mais agudo filósofo estoico dos romanos (LACTANCIO, 1990a, p. 83).

É verdade que é certo o que resenhei que havia dito Séneca em suas 
Exortações (LACTANCIO, 1990a, p. 90).

Não sem graça, Sêneca, em seus livros de filosofia moral, disse isto: << ¿Qual é a causa pela qual, segundo os poetas, o luxurioso Júpiter deixou de ter filhos? [...] (LACTANCIO, 1990a, p. 127).

Com razão, pois, disse Sêneca em "Las Morales" (LACTANCIO, 1990a, p. 169).

Com razão, pois, ri Sêneca da serenidade dos anciãos (LACTANCIO, 1990a, p. 169).

Muito melhor pensou Sêneca, o mais agudo de todos os estoicos (LACTANCIO, 1990a, p. 202).

Quem queira conhecê-los todos, que segura em suas mãos os livros de Sêneca, veracíssimo descritor e duríssimo acusador dos costumes e vícios públicos (LACTANCIO, 199ob, p. 128).

Sêneca terminou suas Exortações com um pensamento admirável (LACTANCIO, 199ob, p. 264).

Quanto melhor e com quanta maior verdade falou Sêneca (LACTANCIO, 1990b, p. 267).

Lactâncio, em que pese não ter poupado Sêneca de críticas, conforme fica pontuado em sua obra, foi condescendente em considerações a respeito ao pensador: "Sêneca podia haver sido um autêntico fiel de Deus se alguém o tivesse ensinado" (LACTANCIO, 1990b, p. 264). Além de tais elogios, ele se referiu às reflexões senequianas sobre a virtude, sobre o comportamento do sábio e sobre Deus, bem como à sua reprovação dos vícios e das paixões (GARCÍA GARRIDO, 1972), o que põe em evidência certa intimidade com as ideias do pensador clássico.

São Jerônimo, ajustado ao espírito do direito canônico, censurou religiosos que, segundo ele, descuidavam-se das leituras evangélicas e 
proféticas, e utilizavam indevidamente seu tempo com autores clássicos. Culpava-os por fazer voluntariamente o que os meninos cristãos faziam por necessidade prática da educação.

Sua crítica à cultura clássica é extensiva à escola "pagã”, que, por necessidade e tradição, oferecia formação aos pequenos cristãos (MARROU, 1998), que, nela, eram devidamente orientados em seus procedimentos.

Apesar da postura em relação aos autores clássicos, que considerava "profanos", as muitas referências de São Jerônimo a Sêneca tem um caráter ascético, como já foi mencionado neste texto, o que pode ser explicado pelo interesse que esse assunto despertava no "Mestre de Dalmata".

Em Adversus Jovinianum, síntese do ascetismo jeroniano, Sêneca foi mencionado com destaque inúmeras vezes. Cabe mencionar especialmente a referência a Do matrimônio, que se perdeu no tempo. Apesar de sua obstinada negação do pensamento clássico por entendê-lo como pagão, São Jerônimo se refere a Sêneca como “nosso Séneca” (GARCÍA GARRIDO, 1972, p. 198).

Assim, São Jerônimo foi peça importante na consolidação do diálogo do cristianismo com o pensamento clássico: seus escritos celebraram a nova visão que se tinha da percepção de Sêneca ao longo da Idade Média e contribuíram para a produção de cópias e para a circulação das ideias desse pensador clássico por meio dos escritos monacais. Não é temerário afirmar que as obras clássicas não ficaram na sombra do esquecimento e/ou perdidas graças a essa interação dos autores cristãos com Sêneca (GARCÍA GARRIDO, 1972).

Com Santo Ambrósio não foi diferente. Em De Officiis, encontram-se recorrentes referências ao pensamento clássico, em especial ao estoicismo, o que põe às claras a influência que o autor recebeu do Pórtico. O fato de o principal destaque ter sido feito a Cícero (106 - 146 a.C.) não chega a desmerecer Sêneca, com o qual São Ambrósio teve uma aproximação indireta. Ele era um assíduo leitor de Lactâncio, que, por sua vez, era um leitor de reflexões senequianas (GARCÍA GARRIDO, 1972). 
Santo Agostinho pode ser considerado o ponto alto da Patrística. Os esforços dos Padres da Igreja que o antecederam para estabelecer um diálogo entre o pensar cristão e o pensar clássico, bem como as diferenças que os particularizavam em seus avanços e recuos, embora tenham ganhado espaços, não tiveram tanta efetividade. Isso se explica até mesmo pelo excessivo zelo e empenho de muitos desses pensadores em conservar a doutrina cristã em sua pureza, em contraponto aos mais arrojados na defesa desse diálogo.

Com Santo Agostinho, no entanto, esse diálogo cristianismo-cultura clássico ganhou espaço, principalmente no que se refere à fé e à razão. Em sua formulação da filosofia cristã, observa-se o pensamento cristão envolvendo a filosofia considerada "pagã": a fé amparada pela razão natural. Isso não significa que a ação agostiniana pôs o pensar cristão no nível do pensar clássico. Nesse seu exercício de diálogo, ele foi sentencioso em declarar que não se devia ter medo das verdades contidas no pensar clássico, pois eles a tem indevidamente, e é dever recuperá-las em favor dos cristãos (MORENO; POBLADOR, DEL RIO, 1986)

Em relação a Sêneca, em que pese tê-lo elogiado por ocasião da reclamação de Macedônio, não parece ter recebido expressiva influência do pensador romano. São poucas as menções a Sêneca em sua imensa obra, mas não se pode negar que esse "Doutor da Igreja" conhecesse escritos senequianos. O fato de ele ter mencionado uma obra de Sêneca, De Superstitione, que não chegou até nós, é um indicativo de que ele transitou pelas reflexões do filósofo.

É possível pensar na presença senequiana em Santo Agostinho, já que este, em suas Confissões, refletiu sobre a formação do príncipe, sobre a ordem, sobre as virtudes cardeais, assuntos também abordados por Sêneca.

No desvendar da possível aproximação entre Santo Agostinho e Sêneca, levantam-se suas discussões sobre os meninos, sobre as semelhanças e as diferenças entre estes e os homens, temática desenvolvida pelo pensador romano, no capítulo XII, Da constância do sábio. Apesar da superficialidade, pois em um cotejamento entre os textos, verifica-se que, se existem 
aproximações, são limitadas: Sêneca discute as semelhanças entre homens e meninos e Santo Agostinho, as faltas que cometem os meninos.

Objeto de comparação são também as duas cidades discutidas por Santo Agostinho e a reflexão de Sêneca sobre as duas repúblicas: uma grande, verdadeira, pública, evolvendo deuses e homens, a outra diz respeito ao local de nascimento. A similaridade de abordagens leva ao entendimento de que os referenciais senequianos podem ter dado luzes às reflexões agostiniana sobre suas duas cidades, uma divina e outra humana (PEREIRA MELO, 2015).

Pode-se considerar, portanto, que Santo Agostinho não desconhecia que Sêneca era um autor e filósofo clássico e que suas reflexões e produções não eram de um pensador preocupado com questões voltadas ao cristianismo. Portanto, deveria ter claro que não se tratava de cânones cristãos, sequer de um pensador às vésperas de uma suposta conversão (OROZ RETA, 1966).

Em Cidade de Deus encontra-se uma das maiores referências de Santo Agostinho a Sêneca. No Livro VI, X, cujo título é "Da liberdade de espírito de Séneca," ele critica a teologia civil com mais veemência do que Varrão criticou a teologia fabulosa". Assim, colocou em tela posições favoráveis ao pensador romano. Referindo-se a De superstitione, hoje perdida, Santo Agostinho destacou suas críticas desfavoráveis a ritos, superstições, práticas e comportamentos, que entendia com indevidos:

\footnotetext{
A liberdade que a Varrão faltou para criticar a teologia civil tão abertamente como a cénica, apesar de tão semelhantes, não faltou, pelo menos em parte, a Aneu Séneca, que, segundo certos indícios, brilhou nos tempos dos Apóstolos: mas, se a teve nos seus escritos, faltou-lhe, porém, na vida. No seu livro contra as superstições (De superstitione), atacou esta teologia urbana muito mais ampla e vigorosamente do que Varrão a dos teatros e das fábulas (SANTO AGOSTINHO, 1996, p. 593).
}

Em outra situação, em Cidade de Deus, ou autor retomou essa discussão com redação e conteúdo bem próximos aos da situação anterior. 


\begin{abstract}
Esta liberdade não a teve Varrão; apenas se atreveu a criticar a teologia poética; na teologia civil - que Séneca demoliu -, nem ousou tocar. Mas, verdade se diga, os templos, onde estes factos se passam, são piores do que os teatros, onde eles se simulam. Por isso, nas cerimónias da teologia civil, a parte que Séneca reserva ao sábio não é a adesão dum coração sinceramente religioso, mas a celebração exterior. Efetivamente, diz ele: $O$ sábio tudo isso observará como coisa ordenada pela lei e não como coisa grata aos deuses (SANTO AGOSTINHO, 1996, p. 596-597).
\end{abstract}

Ainda em Cidade de Deus, Livro XI, capítulo VI, cujo título é "O que Séneca pensava dos judeus”, Santo Agostinho referiu-se novamente ao livro perdido, desta vez para relatar a desafeição e o modo como Sêneca se reportava aos judeus. Afirmava que Sêneca os tratava como "gente perversa" (SANTO AGOSTINHO, 1996, p. 599), condenava seus ritos e a manipulação a respeito de sua deidade:

Eles sabem quais as origens dos seus ritos; mas a maior parte do povo pratica-os sem saber o que faz. Mas estes ritos sagrados porque e em que medida foram instituídos pela autoridade divina, como é que posteriormente esta mesma autoridade divina os retirou, em ocasião oportuna, ao povo de Deus, ao qual foi revelado o mistério da vida eterna - (SANTO AGOSTINHO, 1996, p. 599-600).

Nessa passagem, Santo Agostinho reprovou Sêneca por entender que ele não teve em conta os cristãos, permanecendo neutro, indiferente. "Quanto aos cristãos, já então inimigos declarados dos judeus, não ousou falar deles em qualquer sentido, nem para os louvar contrariamente aos velhos hábitos da sua pátria, nem para os maldizer contrariamente talvez ao seu modo de sentir" (SANTO AGOSTINHO, 1996, p. 599).

Fica expressa a cobrança agostiniana pelo silêncio de Sêneca em relação aos cristãos: se ele teve a coragem de fazer uma crítica severa ao politeísmo, deveria também ter tido a coragem de se regenerar em público pelo culto antigo, particularmente pela religião pátria na qual foi educado (ELORDUY, 1965, p. 182-183). 
Entretanto, a crítica mais contundente de Santo Agostinho a Sêneca também aparece no Livro VI, X, de Cidade de Deus, no qual expressa um juízo de valor particular: havia em Sêneca uma dissonância entre a teoria e a prática, ou seja, o filósofo não vivia conforme suas reflexões (OROZ RETA, 1966).

Todavia, este Séneca, libertado pela filosofia, como convinha a um ilustre senador do Povo Romano, honrava o que censurava, praticava o que reprovava, adorava o que condenava. Quer dizer, a filosofia tinha-lhe ensinado alguma coisa de grande: não ser supersticioso no mundo; mas as leis da cidade e as tradições humanas obrigaram-no, sem descer ao papel de histrião representado ficções no palco, a imitar esse papel no templo - pelo que é tanto mais digno de censura quanto mais praticando esses ritos sem sinceridade, assim procedia para que o povo pensasse que era com sinceridade que procedia; o próprio comediante, ao representar, pretende divertir e não enganar com as suas mentiras (SANTO AGOSTINHO, 1996, p. 597-598).

Também em suas Confissões V, 6, 11, Santo Agostinho fez uma citação indireta e rápida de Sêneca ao avaliar as habilidades formativas de Fausto de Milevo, o Maniqueu (350 - 400), com quem se encontrara em Cartago em 383.

Por isso, logo que se me ofereceu oportunidade, comecei com meus amigos a entrevista-lo, numa ocasião em que não nos era indecoroso discutir. Expus-lhe algumas dúvidas das que me preocupavam. Notei que das artes liberais apenas sabia a gramática, e, ainda esta, de modo nada extraordinário. Porque ele tinha lido alguns discursos de Cícero, pouquíssimos tratados de Sêneca, alguns trechos de poetas e os poucos livros da seita elegantemente escritos em latim, e, além disso, porque se exercitava cotidianamente na oratória, tinha adquirido esta facilidade de falar, que o bom emprego do seu talento e certa graça natural tornavam mais agradável e sedutora (SANTO AGOSTINHO, 1980, p. 77-78)

As poucas menções ao pensamento senequiano nas reflexões agostinianas levam a pensar na pouca influência do pensador clássico sobre o cristão. Contraditoriamente, não seria incongruente presumir uma influência doutrinária, mas, como ele não se manifestava a esse respeito, reputam-se tais 
menções como mera eventualidade (OROZ RETA, 1966). Um fato não pode ser negado: Santo Agostinho teve acesso à obra senequiana, inclusive a livros não conhecidos em nossos dias. Assim, mesmo que Sêneca não tenha alcançado o prestígio de um Cícero junto ao "Doutor da Igreja", seus pensares foram uma realidade a rondar sua vida.

Enfim, esse grande movimento encetado por grandes nomes do cristianismo no acolhimento do pensamento de Sêneca teve como resultado a elaboração de um sensível, poderoso e original corpo doutrinal e formativo. Nisso, que se tornou a paidéia cristã, o amparo e o aporte da paidéia grega foram fundamentais, pois muitos de seus conteúdos eram compatíveis com o que se pretendia transmitir na educação cristã. Do mesmo modo que o corpus pleno da paidéia grega era constituído pela literatura grega, na qual estavam representadas as regras mais altas da vida humana, em sua forma mais duradora e perene, a Bíblia apresentou-se como o referencial máximo para a paidéia cristã. Na primeira, a imagem do homem ideal é o grande paradigma (JAEGER, 1998). Na segunda, o paradigma é Cristo, e seu conteúdo pode ser encontrado tanto no Antigo Testamento quanto no Novo: a grande verdade formativa está na "boa nova" trazida por Jesus.

É possível que a temática abordada neste texto esbarre em objeções e/ou contestações, mas é preciso ressalvar: o Sêneca cotejado, lido e debatido pelos pensadores cristãos não era o Sêneca voltado para a literatura, o ensaísta e o tragediólogo. O diálogo estabelecido pelos cristãos era com o filósofo preocupado com a moral, com o processo formativo do homem, o homem moral ideal, ou seja, preocupado em recuperar o homem por meio de uma exortação moral. Esta preocupação tinha uma sintonia fina com a preocupação dos cristãos, que também postulavam a formação de um homem ideal que atendesse às demandas do cristianismo. 


\section{CONSIDERAÇÕES FINAIS}

Os pensadores cristãos analisados neste texto representam fases e processos distintos de orientação do cristianismo. Cada um a seu tempo, com base nas demandas que a sociedade impunha ao cristianismo, colocaram seus saberes e pensares a favor da religião que ajudavam a fundamentar e a consolidar. Nesse processo, buscaram sustentação filosófica para os fundamentos cristãos, fundada tanto na afetividade propagada por Jesus quanto na racionalidade própria do pensar considerado pagão.

Os pensadores cristãos destacavam-se entre os primeiros mediadores no processo de transformação e de reorientação doutrinal da Igreja que se firmava, quer para atender aos matizes sociais mais intelectualizados que, por interesses diversos, foram levados à conversão, quer para defender a universalidade da doutrina. De forma mais tímida ou mais ousada, cada um deles encontrou um modo de se apropriar, utilizar e adequar aspectos do pensamento clássico, particularmente de Sêneca, aos interesses imediatos da doutrina, mesmo que, contraditoriamente, negassem a fonte que punham a seu favor.

Esse comportamento ambíguo e pendular de aceitação e negação teve como resultado um ajuste positivo no pensamento doutrinal que queriam efetivar. Além disso, nesse processo de apropriação, adequação e ajustes, eles demonstraram criatividade, pois, à medida que lançavam mão desse expediente, dando sustentação e fundamentação aos princípios e/ou regras morais deixadas por Cristo, não descaracterizaram plenamente a originalidade de seus princípios. A afetividade fundada no amor ganhou o ingrediente do pensar filosófico, fundado na ciência, anunciando os novos tempos que estavam por vir.

Considerando esse processo de assimilação, apropriação e interação do cristianismo com a cultura clássica, bem como o poder e a influência que conquistou no tempo, pode-se afirmar que o cristianismo, não criou uma civilização, mas preservou civilizações: penetrou-as, assumiu-as, recolheu-as e 
modelou-as segundo seu próprio interesse, sua perspectiva e seu objetivo. Nessa esteira, suprimiu, eliminou e combateu todo o conteúdo que não estivesse em consonância com as orientações oriundas dos textos sagrados, especialmente do Antigo e Novo Testamento. Em uma escalada corretora, transformou a seu favor o que não era possível aceitar sem a devida adequação, providenciou a assimilação do que contemplava como bom, exaltou o que ainda não havia conseguido atingir sua perfeição (MARROU, 1960, p. 66).

Em termos conclusivos, vale lembrar que esse diálogo criador do cristianismo com as ideias pulsantes da tradição clássica provavelmente revestiu o pensamento cristão da segurança a respeito de sua própria universalidade, o catolicismo (JAEGER, 1998, p. 62). Isso lhe afiançou a certeza da efetividade do seu corpo doutrinal e refletiu-se em seu magistério, por meio do qual orientou e guiou a vida dos homens.

\section{REFERÊNCIAS}

AGOSTINHO, Santo. Confissões. São Paulo: Abril Cultural, 1980 (Os Pensadores).

AgOSTINHO, Santo. A Cidade de Deus. Petrópolis: Vozes, 1999, vol. I.

AGUSTIN, San. Cartas. Madrid: Biblioteca de Autores Cristianos, Tomo XI, 1953.

ELORDUY, Eleuterio. Séneca, protector del cristianismo. Pruebas documentales. In: PONENCIAS Y CONFERENCIAS PARA LAS SESIONES PLENARIAS, 1965, Madrid. ACTAS del Congreso Internacional de Filosofia en Conmemoracion de Seneca, en el XIX Centenario de su Muerte. Madrid: Ed. Sanchez Leal, 1965, p. 181-206.

GALINO, María Ángeles. Historia de la educación. Edades antigua y media. Madrid: Editorial Gredos, 1988.

GARCÍA GARRIDO, José. Sêneca en el pensamiento pedagógico da la Antiguidad cristiana y del medievo. Revista Española de Pedagogía. Madrid: vol. XX, n.118, p.193-205, abr-jun. 1972. 
GÓMEZ MARTÍNEZ, Luis. Sêneca cristão?. Revista Portuguesa de Filosofia. Braga, Abril-Junho, Tomo. XXII, 1966, p. 132-146.

HOBSBAWM, Eric. Sobre História. São Paulo: Companhia das Letras, 2005.

JAEGER, Werner. Cristianismo Primitivo y Paideia Griega. México:

Fondo de Cultura Economica, 1998.

JERÓNIMO, San. De viris illustribus. Sobre los hombres ilustres. Sevilla: Editorial Apostalado Mariano, 1999, p. 17-18.

LACTANCIO. Instituciones Divinas. Libros I-III. Madrid: Gredos, $1990 a$. LACTANCIO. Instituciones Divinas. Libros IV-VII. Madrid: Gredos, $1990 \mathrm{ob}$ MANJARRÉS, Júlio Mangas. Sêneca o el poder de la cultural. Madrid. Debate, 2001.

MARROU, Henri-Irénée. Historia de la educación en la Antigüidad. México: Fondo de Cultura Economica, 1988.

MARROU, Henri-Irénné. "Introducción”. CLEMENTE DE ALEJANDRÍA. Le Pedagogue. Paris: Du Cerf, 1960.

MORENO, Juan Manuel; POBLADOR, Alfredo; DEL RIO, Dionisio. Historia de la educación. Edades Antigua, Media y Moderna Acción Pedagógica Contemporánea. Madrid: Paraninfo, 1986.

OROZ RETA, José. Séneca en San Agustín. IN: Estudios sobre Séneca. Octava semana española de Filosofía. Madrid: Consejo Superior de Investigaciones Científicas, Instituto Luis Vives y Socied Española de Filosofia, 1966, p.331-351.

PEREIRA COELHO, João Paulo; PEREIRA MELO, José Joaquim. O oficio do historiador: reflexões sobre o conceito de passado em suas dimensões socias e históricas. Revista História \& Perspectivas, Ufu, Uberlândia, v. 30, n. 57, p. 209-232, jul./dez. 2017.

PEREIRA MELO, José Joaquim. O sábio senequiano: um educador atemporal. Maringá: Eduem, 2015.

PEREIRA MELO, José Joaquim. Fontes e Métodos: sua importancia na descoberta das heranças educacionais. In: COSTA, Célio Juvenal; PEREIRA MELO, José Joaquim; FABIANO, Luiz Hermenegildo (org.). Fontes e Métodos em História da Educação. Dourados: Editora UFGD, 2010, p. 1334 . 
REDONDO, Emilio; LASPALAS, Javier. Historia de la educación. Edad Antigua. Madrid: Dykinson, 2002.

RODRÍGUES FERNÁNDEZ, Celso. Epistulae morales ad Lucilium: Séneca cristiano. In: SÉNECA DOS MIL AÑOS DESPUÉS, 1996, Córdoba. ACTAS del congreso Internacional Conmemorativo del Bimilenario de su

Nacimiento. Córdoba: CajaSur Publicaciones, 1996, p. 307-332.

SÉNECA, Lúcio Aneu. Cartas a Lucílio. Lisboa: Fundação Calouste Gulbenkian, 1991.

TERTULIANO. Acerca del alma. Madrid: Ediociones Akal, 2001.

ULLMAN, Reinholdo Aloysio. O estoicismo romano. Porto Alegre: EDIPUCRS, 1996.

JOSÉ JOAQUIM PEREIRA MELO é professor no Departamento de Fundamentos da Educação e no Programa de Pós-Graduação em Educação da Universidade Estadual de Maringá (UEM). Mestre, Doutor e Pós-Doutor em História e Sociedade pela Universidade Estadual Paulista Júlio de Mesquita Filho, Campus Assis (UNESP). Lidera o Grupo de Pesquisa Transformações Sociais e Pensamento Educacional (CNPq).

E-mail: pereirameloneto@hotmail.com

(b) http://orcid.org/0000-0002-0743-8000

Recebido em: 20 de março de 2020

Aprovado em: 07 de abril de 2021

Editora responsável: Terciane Luchese

Associação Sul-Rio-Grandense de Pesquisadores em História da Educação - Asphe

Artigo de acesso aberto distribuído nos termos de licença Creative Commons. 